Volume 7 Issue 1, March 2020

Nationally Accredited Journal,

Decree No. B/4130/E5/E5.2.1/2019

\title{
The Position Of Attorney Power Of Charge Mortage Right Made By Notice With The PPAT Format Required From The Act Number 2 Of 2014 On The Position Of Notary In Pemalang City
}

\begin{abstract}
Yusuf Ady Kurniawan ${ }^{1}$ and Dian Rahayu Windyastuti ${ }^{2}$
Abstract. The summary of the issues in this study is 1) how is the implementation of the Authorization of Authorization of Liability in the Barriers currently under way? 2) what are the issues raised in the implementation of the current Authorization of Burden of Rights on the Barriers? 3) How should the implementation of the Authorization of the Liability of the Liability of Barriers be made? The type of research used is sociological juridical. The result of this study is that there is a disharmony between the provisions of Article 38 of the Notary Department Law and Article 96 paragraph (1) of Equity No. 8 The of 2012. The factor affecting the emergence of the question in the making of the SKMHT is that the regulatory factor is disharmonization between Article 38 of the Notary Department Law and Article 96 paragraph (1) of Civil Code. 8 of 2012, Keywords: Position; Warrant of Burden of Rights; Notary.
\end{abstract}

\section{Introduction}

All Notaries will use the BPMHT by the BPNH, unless they use the form and format provided, the SKMHT will not be accepted by the BPN. Whereas Article 15 paragraph (1) of Act No. 4 The year 1996 explicitly states that the SKMHT was "made" by the Notary. By simply filling in the blank / form of the MCMC provided by the BPN, it means that the Notary does not make an authentic deed, but rather makes a false letter. This is not in line with the Notary's authority to make other authentic and authoritative acts as set out in Article 15 paragraph (1) and paragraph (2) of Act No. 30 of 2004 as amended by Act No. 2 of 2014. In accordance with this provision, the Notary does not fill out the deed as in filling the SKMHT.

Based on the various reasons described above, it is clear that the question of making the MCMC in the form of a draft deed that is not in accordance with Act No. 30 of 2004 as amended by Act No. 2 The of 2014 has resulted in legal uncertainty in the drafting of the MCMC in Liability Law. According to Syafruddin Kalo, "the certainty of the law we can see from two angles, the certainty of the law itself and the certainty of the law." Syafruddin Kalo further states that: ${ }^{3}$

The certainty in the law meant that each of these legal norms had to be formulated with sentences within it that did not contain different interpretations. As a result, they will bring lawless or compliant behavior. In practice there are many instances of legal events, which when confronted with the substance of the rules of law governing them, are sometimes unclear or inadequate, resulting in distorted interpretations that can

\footnotetext{
${ }^{1}$ Student of Master of Notary Law, Sultan Agung Islamic University (Unissula) Semarang email yusufady19@gmail.com

${ }^{2}$ Student of Master of Law Program, Faculty of Law, Universitas Islam Sultan Agung email dianrahayu.wnd@gmail.com

${ }^{3}$ Syafruddin Kalo, "Penegakan Hukum yang Menjamin Kepastian Hukum dan Rasa keadilan Masyarakat" is quoted from http://www.academia.edu.com accessed December 8, 2016, p. 4.
} 
lead to uncertainty. The certainty in the law meant that each of these legal norms had to be formulated with sentences within it that did not contain different interpretations. As a result, they will bring lawless or compliant behavior. In the practice of many legal events.

Further Satjipto Rahardjo as quoted by Syafruddin Kalo says that: ${ }^{4}$ One of the aspects of legal life is certainty, that is, the law wants to create certainty in the relationship between people in society. One of the most closely related issues of certainty is the issue from which the law came from. The certainty of the origin or source of the law has been important since the law became more formal.

Then Hurricane Husband of the Year and Rahmi Purnama Jasmine said: ${ }^{5}$ In his field practice we can see many justice-seeking societies, especially the weak economists, who do not have legal certainty. This is due to the long judicial process in Indonesia, and the cost that is quite expensive, while the purpose of the court is to establish legal certainty.

In view of the opinions of various legal experts it appears that the drafting of the SKMHT as described above has resulted in legal dualism and even legal remedies regarding the making of the Notary. The same thing happened in Pemalang area. Where the SKMHT manufacturing system in Pemalang also has something in common with the preparation of SKMHT in general. This is because of the provisions regarding the blanking form / form of SKMHT as set forth in Article 96 paragraph (1) of PMNA / PerKaban No. 3 of 1997 as amended by Code No. 8 Of 2012 still applies throughout Indonesia to this day.

A summary of the issues to be considered in this study is 1) How is the implementation of the Authorization of Authorization of Liability in the Barangay at present? 2) What are the issues raised in the implementation of the current Authorization of Burden of Rights on the Barriers? 3) How should the implementation of the Authorization of the Liability of the Liability of Barriers be made?

\section{Research Methods}

This study uses normative jurisprudence research methods, using a legislative and conceptual approach. The type of research that the author is involved in is descriptive research. data collection in this study is by collecting (documentation) secondary data in the form of documents, archives, literature, and supporting.

\section{Results And Discussion}

\subsection{Implementation of the Authorization of the Authorization of Burden of Liability in the Current Barrier}

The Power of Burden of Rights or the so-called SKMHT is the authorization of one legal subject (person / body of law) to another subject (person / legal entity) (legal person) to perform a particular matter. This particular matter (special power) is, of course, the exercise or exercise of the burden of the Rights in the form of the Grant of Rights (APHT) Act. Upon the issuance of the APHT, it shall be the authority of the respective Holders (creditor) of the parties to the APHT to register at the Land Office. In the Land

\footnotetext{
${ }^{4}$ Satjipto Rahardjo, IImu Hukum, Aditya Bakti Image, Bandung, 2012, p. 4 and 16.

${ }^{5}$ Badai Husain Hasibuan dan Rahmi Purnama Melati, "Asas Kepastian Hukum Dalam Peradilan Indonesia" is quoted from http://www.amiyorazakaria.blogspot.com accessed December 9, 2016, p. 1.
} 
Office the APHT registration process is based solely on the APHT by attaching the SKMHT as the basis of the APHT.

As for the establishment of the MCMC other than the Notary, it is also assigned to the Office of the Land Act or PPAT whose presence extends to the district area, in order to facilitate the provision of service to the needy. It is stated in Article 15 paragraph (1) of Act No. 4 of 1996 which states that: "A Certificate of Authorization of Liability shall be made by the Notary Act or the PPAT Act ....". In accordance with this provision, the Notary has the authority to make SKMHT with the act. This means that the SKMHT made by the Notary must be made in the form of a deed, but in practice the making of the SKMHT by the Notary is the same as filling in the blank / form / form provided by the land agency. As to the form of the SKMHT, it is expressly set forth in Article 96 paragraph (1) of the Minister of State of Agraria / Head of National Land Agency No. 3 of 1997 on the Provision of the Government of Regulation No. 24 of 1997 on Land Registration to be hereafter referred to as PMNA / Perawaban No. 3 of 1997 as amended by the National Head of Land Regulation No. 8 of 2012 to be hereafter referred to as Perkaban No. 8, 2012. ${ }^{6}$ According to this Article, the form of the SKMHT used in the granting of HT and its filling procedure shall be in accordance with and in accordance with the attachment set forth in PMNA / Per No. 3th May 1997 as amended by Sec. 8 of 2012. In addition, Article 96 paragraph (3) of PMNA / Per corporation 3 of 1997 is as amended by Subsection 8 of 2012.

Subsequently pursuant to Article 38 of the Act, the SKMHT made under the Notary Act pursuant to Article 96 paragraph (1) of Equity No. 8 Of 2012 (Subsidiary) does not qualify as a Notary Act, so the Notary in making SKMHT can not only refer to Article 96 paragraph (1) of Occupation but must also comply with all the provisions of Article 38 of the Act No. 30 of 2004 jo. Act No. 2 of 2014 on Notary Department Law (UUJN). If the Notary continues to comply with the provisions of Article 96 paragraph (1) of the Incorporation in making the MCMC and in contravention of Article 38 of the National Department of Law, the Notary has acted outside the provisions of the making of the Notary Authenticity Act, so the MCMC is made under the Notary Act under Article 96 paragraph (1) ) The corporation does not meet the criteria of an Notary authentic act. The same is happening in Pemalang District, Deden Deni as the National Land Liaison Office of Pemalang Regency informs us that the registration of delegated Rights is made through the Authorization of Lending Rights with the following charges: ${ }^{7}$

- Rp. 50,000.00 for liens up to a value of up to Rp. 250,000,000,00;

- Rp. 200,000.00 for the right to a value of Rp. 1,000,000,000.00;

- Rp. 2,500,000.00 for lien with a value of Rp. 10,000,000,000.00;

- Rp. 25,000,000.00 for lien with a value of Rp. 1,000,000,000,000,000.00;

- Rp. 50,000,000.00 for lien with value above Rp. 1,000,000,000,000.00.

In the process, according to Deden SKMHT made use of the form prepared at the BPN office filled by the parties who wanted to create SKMHT. In view of the making of the existing SKMHT there has been a disharmonization among Article 38 of the Notary Department Act with Article 96 paragraph (1) of Subsection No. 8 of 2012. In accordance with the provisions of Article 1868 of the Penal Code, the authentic act is an act made before or by a public official appointed thereon.

\footnotetext{
${ }^{6}$ LOC, cit.

7 Deden Deni, Pembuatan SKMHT Di Pemalan,personal interview with Head of section Law Relationship BPN of Pemalang Regency
} 
The terms made mean that the beginning and end processes are PPAT jobs. It is not in the context of filling in the blank (blank) form of the PPAT that came before the publication of Item No. 8 of 2012, if it is linked to the responsibility of a PPAT being fulfilled. If a procedure is not fulfilled, and the procedure is not fulfilled, then the act by judicial process can be declared as an act having the power of proof as a deed under the hand. If such a position has been established, then the value of the proof is passed to the judge.

The Article 1888 states that the power of proving the validity of an act is in its original form, so that the SKMHT made by the Notary act under Article 96 paragraph (1) of the said corporation does not have the complete proof of written evidence because it is not clearly determined which is the original. On the other hand under Article 1868 of the Civil Code on the provision of an authentic act, the SKMHT made under a Notary Act under Article 96 paragraph (1) of the said Act does not meet the provisions of an authentic act, where the act is made in the form prescribed by law, made by the official authorized (Notary who is subject to Article 38 of the UUJN, but is subject to Article 96 paragraph (1) of the Commonwealth). Imagine if the debtor understood this and slowed down the process of waiving the Liability where the loan or credit had been received. As a result of this legalization of law the law regarding SKMHT has no legal certainty.

The question of this uncertainty has led to the collapse of existing legal justice. Without justice, policy and or rule of law are not lawful. If, in law enforcement, it tends to the value of legal certainty or derives from its legal aspects, then as a legal value has shifted the value of justice and value / usefulness. This is because, to the most important certainty of the law, the rule itself is in accordance with what is formulated. Similarly, when the value of usefulness / usefulness is greater, then value / usefulness shifts the certainty of law or the value of justice because the most important value of usefulness is the fact that the law is beneficial / useful to society. This is also true when the attention is only on the value of justice, it has the effect of shifting the value of legal certainty and usefulness. This implies that in law enforcement there must be a balance between these three values. ${ }^{8}$

With regard to justice there are many different perspectives, justice is based on equality, based on the principle that the law binds everyone, so that justice to be achieved by law is understood in the context of equality. The similarities here are based on numerical similarity and proportionality. Numerical equality is principally the degree of equality for every person before the law, while proportional equality is for giving everyone what is rightfully theirs. Distributive justice, this is identical with proportionate justice, where distributive justice is based on the giving of rights in proportion to the small size of services, so in this case justice is based on equality, rather than its proportion (proportionally). Corrective justice, ${ }^{9}$

\subsection{The Issues in the Making of a Warrant to Impose Liability}

During the development of the MCMC there were several issues that led to the lack of clear legal powers. One of them is:

\subsubsection{Legal Issues}

\footnotetext{
${ }^{8}$ LBH Struggle, 2010, Penegakan Hukum Yang Menjamin Keadilan, Kepastian Hukum Dan Kemanfaatan (Studi Kasus: Kasus Mbah Minah). http: // more struggle. blogspot.com/2010/10/en-forcement-of-investment.html, accessed January 4, 2020.

${ }^{9}$ LoC, cit.
} 
Volume 7 Issue 1, March 2020

Nationally Accredited Journal,

Decree No. B/4130/E5/E5.2.1/2019

It has been explained above that there has been a discrepancy between Article 38 of the Notary Department Law and Article 96 paragraph (1) of Equity No. 8 of 2012. Article 38 of the Notary Department Law states that:

- Each Act comprises: beginning of Act or head of Act; body of the Act; and end or closing of the Act.

- The beginning of the Act or the head of the Act contains: title of Act; Act number; hours, days, dates, months, and years; and the full name and position of the Notary.

- The body of the Act contains: full name, place and date of birth, the contents of the Act which are the wishes and wishes of the stakeholders; and full name, place and date of birth, as well jobs, positions, positions, and places; stay of every known witness.

- End or end of the Act includes: a description of the reading of the Act as referred to in Article 16 paragraph (1) of the letter $m$ or Article 16 paragraph (7); a description of the signing and place of signing or translation of the Act if any; the full name, place and date of birth, occupation, title, position and residence of each witness of the Act; description of the absence of change occurs in the making of an Act or a description of any changes which may be incurred, incurred, or substituted and the number of such changes.

- The Notary Substitute Notices and Temporary Officers Notaries Act, in addition to containing the provisions as referred to in paragraph (2), paragraph (3), and paragraph (4), also contains the number and date of appointment of the appointee, as well as the officer in office.

Meanwhile pursuant to Article 96 paragraph (1) of Equity No. 8 The of 2012 forms of the deed used in the drafting of the Warrant of Assignment of Rights include:

- Buy and Sell Act

- Exchange Act

- Grants Act

- Companies Incorporation Act

- Mutual Rights Assignment Act

- Warranty Grant of Liability

- Building / Property Rights Grant

- Authorization to Impose Liability

Meanwhile the existing MCMC format is not in accordance with the script as intended under Article 38 of the Notary Department Act but in the form of a local BPN. This halk could clearly result in legal uncertainty in terms of the statutory powers of the existing Warranty. This lack of certainty would result in legal infringement as a result of human rights violations as set out in Article 28D of the Constitution of 1945 . As well as violations of the Patent Signs.

\subsubsection{Question of SKMHT Weaknesses As Act}

Subject of the SKMHT Subject as to the following SKMHT issues:

- In Article 15 paragraph (1) of the UUHT on the timeliness of the use of the SKMHT to guarantee certain repayments Thus, as explained in Article 15 paragraph 1 letter (a) the UUHT requires that the power of indemnification be made solely by authorizing the burden of liability alone, so it is also separate from the other acts. The power to impose Liability cannot be consolidated with credit agreements, but must be made separately. 
- The deadline for SKMHT can be due to a few things:

- Warrant of Authorization of Warranty is void by law because registration of uncharted lands is subject to a lengthy process that is beyond the time limit specified by Article 15 of the Act;

- Damaging the Bank's interest due to such short term lending is not possible even if the credit has been given for three months, not because the bank's analysis of the business eligibility will be bad but the crash could be the result of economic change or regulatory change. abroad and within the State.

- With the issuance of the deed of guarantee and the Warrant of Authorization of Warranty with the deed of registration and the registration thereof, the obligation will inevitably incur additional costs to the debtor.

- The various disadvantages of the drafting of the Warranty Authorized Warrant as described above have led to the legal uncertainty in the drafting of the Warranty's Grant of Warranty especially in the Barangay area.

\subsection{The Implementation of the Authorization of the Authorization of the Authorization of the Liability of the Liability of a Proposed Barrier}

It has been explained above that the position of the SKMHT is made in accordance with Article 96 paragraph (1) of Equity No. 8 The of 2012 is not correct, the SKMHT made under the Notary Act should be in accordance with the provisions of Article 38 of the Act to meet the criteria as a Notary Act. It is up to the National Land Agency of the Republic of Indonesia (BPNRI) to review the provisions of Article 96 paragraph (5) for the implementation of the Land Rights Registration of the Land Office on the MCMC made under the Notary Act under Article 38 of the Act No. 2 of 2014 is acceptable.

Accordingly, it is necessary to abolish the provisions as intended by Article 96 paragraph (1) of Equity No. 8 of 2012 under the provisions of Article 38 of the Act No. 2 of 2014 hierarchical rule of law as intended in Article 10 of Act No. 12 of 2011 jo. Act No. 15 of 2019 on the National Code of Law. It is also due to the fact that the SKMHT form does not fall under the category of valid certificates under the relevant legislation. So in the future the drafting of the MCMC should be fully submitted to the Notary and / or PPAT with full authority as set out in the No. 2 Of 2014 Law on the Notary Department. Legal certainty is one of the goals that the law seeks to achieve as part of an effort to realize justice. The actual form of legal certainty is the enforcement or enforcement of an act regardless of the subject matter of the perpetrator or the perpetrator. There is a legal certainty that every legal subject can predict what will happen / experience when performing a particular legal action. Certainty is needed to realize the principle of equality in the law without discrimination or discrimination. There is a legal certainty that every legal subject can predict what will happen / experience when performing a particular legal action. Certainty is needed to realize the principle of equality in the law without discrimination or discrimination. There is a legal certainty that every legal subject can predict what will happen / experience when performing a particular legal action. Certainty is needed to realize the principle of equality in the law without discrimination or discrimination. ${ }^{10}$

To establish principles maqasid al syariah the provisions of Civil Code No. 8 of 2012 should be subject to judicial review as they may result in the contravention of Pancasila and Article 28D of the Constitution 1945 as a result of legal uncertainty in the

\footnotetext{
${ }^{10}$ Moh. Mahfud MD, "Penegakan Hukum DanTata Kelola Pemerintahan Yang Baik", Bahan pada Acara Seminar Nasional "Saatnya Hati Nurani Bicara" held by DPP HANURA. Jakarta Constitutional Court, January 8, 2009.
} 
Volume 7 Issue 1, March 2020

Nationally Accredited Journal,

Decree No. B/4130/E5/E5.2.1/2019

jurisdiction of the SKMHT. So the law relating to SKMHT is capable of strong legal power and capable of delivering justice. This is what Satjipto Rahardjo intended to say that the law should be capablechange quickly, make a fundamental reversal in theory and legal praxis, and breakthroughs. The liberation is based on the principle that the law is for man and not vice versa and that the law does not exist for himself, but rather for something greater namely human dignity, happiness, prosperity, and human dignity. ${ }^{11}$

\section{Closing}

\subsection{Conclusion}

- The existence of disharmony between the provisions of Article 38 of the Notary Department's Law and Article 96 paragraph (1) of Subsection No. 8, 2012.

- The factor affecting the emergence of the question in the drafting of the MCMC is that the regulatory factor is disharmonization between Article 38 of the Notary Department Law and Article 96 paragraph (1) of Subsection No. 8, 2012

- The weaknesses of the SKMHT are the existence of the SKMHT and the additional cost of making the SKMHT which is also a notary certificate.

\subsection{Suggestion}

Removal must be made in accordance with the provisions of Article 96 paragraph (1) of Equity No. 8 of 2012 contrary to the provisions of Article 38 of Act No. 2 Of 2014. In addition, BPN must actively monitor the implementation and implementation of SKMHT. As well as creditors should be able to reduce the intensity of use of SKMHT.

\section{References}

[1] Abdul Ghofur Anshori, 2009, Lembaga Kenotariatan Indonesia (Perspektif Hukum dan Etika), UII Press, UII Press, Yogyakarta

[2] AA. Andi Prajitno, 2010, Himpunan Peraturan Perundang-Undangan Jabatan Notaris Di Indonesia, $1^{\text {st }}$ Print, Putra Media Archives, Jakarta

[3] Gatot Supramono, 2013, Perjanjian Utang Piutang, Kencana, Jakarta

[4] Made Oka Cahyadi Wiguna, Surat Kuasa Membebankan Hak Tanggungan dan Pengaruhnya Terhadap Pemenuhan Asas Publisitas dalam Proses Pemberian Hak Tanggungan, Journal of Indonesian Legislation, Volume 14 Number 04, December 2017, General Directorate of the Ministry of Law and Human Rights, Jakarta, 2017

[5] Syafruddin Kalo, "Penegakan Hukum yang Menjamin Kepastian Hukum dan Rasa keadilan Masyarakat" cited from http://www.academia.edu.com accessed December 8, 2016

[6] Satjipto Rahardjo, 2012, I/mu Hukum, Aditya Bakti Image, Bandung

[7] Hurricane Husband and Full Moon Jasmine, "Asas Kepastian Hukum Dalam Peradilan Indonesia" cited from http://www.amiyorazakaria.blogspot.com accessed December 9, 2016

\footnotetext{
${ }^{11}$ Satjipto Rahardjo, 2004. Ilmu Hukum; Pencarian, Pembebasan dan Pencerahan, Muhammadiyah Press University, Surakarta.
} 


\section{JURNAL AKTA}

eISSN : 2581-2114, pISSN: 2406-9426

[8] Gemilang Works, 2009, Himpunan Peraturan Perundang-undangan Jabatan Notaris dan PPAT, Indonesia Legal Center Publishing, Jakarta

[9] Lumban Tobing, 1980, Peraturan Jabatan Notaris, Erlangga, Jakarta

[10] Gatot Supramono, 2013, Perjanjian Utang Piutang, Kencana, Jakarta

[11] Trisadini Prasastinah Usanti and Leonora Bakarbessy, 2014, Buku Referensi Hukum Perbankan: Hukum Jaminan, Revka Petra Media, Surabaya 